\title{
An Assessment of the Expertise Required of Workers, in the Context of Their Capacity to Cope With Libya's Fourth Industrial Revolution
}

\author{
E., Mohamad ${ }^{1}$, H.T., Saeid Balrwein ${ }^{1}$, M.A., A Rahman ${ }^{1}$, \\ N.A. A., Nor Azlan ${ }^{1}$ M.S., Abd Rahman ${ }^{2}$ and A., Saptari ${ }^{3}$ \\ ${ }^{1}$ Fakulti Kejuruteraan Pembuatan, Universiti Teknikal Malaysia Melaka, Hang Tuah Jaya, 76100 Durian \\ Tunggal, Melaka, Malaysia \\ Email: effendi@utem.edu.my, hussein1981eng@gmail.com, arfauz@utem.edu.my, \\ alyaanorazlan@gmail.com \\ ${ }^{2}$ Fakulti Teknologi Kejuruteraan Mekanikal dan Pembuatan, Universiti Teknikal Malaysia Melaka, Hang \\ Tuah Jaya, 76100 Durian Tunggal, Melaka, Malaysia \\ Email: soufhwee@utem.edu.my \\ ${ }^{3}$ Department of Industrial Engineering, President University, Jl. Ki Hajar Dewantara, Kota Jababeka, \\ Cikarang Baru, Bekasi 17550 - Indonesia \\ Email: adi.saptari@president.ac.id
}

\begin{abstract}
The advent, of Libya's fourth industrial revolution (4IR), rendered the structure of the country's smart factories exceedingly intricate, vibrant and variable. Several investigators, in this domain, believe that the most significant factors, influencing the outcome of Libya's 4IR, are the skills gap and manpower development issues. In order for the 4IR to progress, it is crucial that more sophisticated capabilities be developed. This undertaking should begin with an assessment of the existing expertise of the stakeholders themselves (self-evaluation). The purpose of this exercise, is to identify the deficiency in skills, with regards to the skill sets, that are essential for the 4IR. This calls an evaluation of the stakeholders' degree of comprehension regarding the 4IR, and their willingness to involve themselves in this exercise. Stakeholders both within and beyond Libya's manufacturing division, should be taken into account for this evaluation. The main objective, of this study, is to ascertain the impact of $4 \mathrm{IR}$, on the aspects of human labour and work organization. To achieve this objective, we opted for the quantitative method. A questionnaire was formulated to scrutinize every single detail in the manpower's supply chain, stretching from Libya's learning system to its workforce.
\end{abstract}

Keywords: Industry 4.0, Skills Gap, Awareness and Readiness, Libyan Manpower

\section{ABSTRAK}

Munculnya revolusi industri keempat Libya (4IR), membuat struktur pabrik pintar di negara itu sangat rumit, dinamis, dan bervariasi. Beberapa peneliti, dalam domain ini, percaya bahwa faktor paling signifikan, yang mempengaruhi hasil 4IR Libya, adalah masalah kesenjangan keterampilan dan pengembangan tenaga kerja. Agar 4IR dapat berkembang, kapabilitas yang lebih canggih harus dikembangkan. Upaya ini harus dimulai dengan penilaian keahlian yang ada dari para pemangku kepentingan itu sendiri (evaluasi diri). Tujuan dari latihan ini, adalah untuk mengidentifikasi kekurangan dalam keterampilan, yang berkaitan dengan perangkat keterampilan, yang penting untuk 4IR. Ini membutuhkan evaluasi tingkat pemahaman para pemangku kepentingan tentang 4IR, dan kesediaan mereka untuk melibatkan diri dalam latihan ini. Pemangku kepentingan baik di dalam maupun di luar divisi manufaktur Libya, harus diperhitungkan dalam evaluasi ini. Tujuan utama studi ini adalah untuk mengetahui dampak 4IR terhadap aspek ketenagakerjaan dan organisasi kerja. Untuk mencapai tujuan ini, kami memilih metode kuantitatif. Kuesioner dibuat untuk mempelajari setiap detail dalam rantai pasokan tenaga kerja, mulai dari sistem pembelajaran Libya hingga tenaga kerjanya

Kata kunci: Industry 4.0, Gap Ketrampilan, timgkat pemahaman dan kesiapan, Libyan tenaga kerja 1. Basic Information 
As the main driver of Libya's economic development, manufacturing division be constantly subjected to innovation, learning and research (Westkämper, 2014). Industrial development represents the most practical means, for developing countries, to draw level, with the economies of developed countries, and in the process, elevate their citizens' quality of life. Industrial development is proving to be more crucial for developing countries now, more than ever (Naudé and Szirmai, 2012, Gehrke et al., 2015). Africa in particular, has turned out to be a glaring disappointment, when it comes to post-independence industrial development. Thus, it is essential that a strategy be conceived, to enable developing countries overcome the present-day obstacles, hampering their industrial development (Naudé and Szirmai, 2012).

In the context of new manufacturing practices, industries in developing countries need to be well-informed on developments in the areas of employment, industrial concentration, and manpower expertise. On-going developments in the manufacturing field, has given rise to significant differences, between conventional and modern-day approaches. The transition, from conventional to modern-day approaches, considerably alters the role of the industrial sector, when it comes to the economy of a country, and its national manufacturing policy ( Swezey and McConaghy, 2011). In 2012, the McKinsey Global Institute (MGI) reported that advancements, in the manufacturing domain, should be accompanied with a strategy that promotes productivity and innovation, instead of a strategy aimed at realizing mass employment (Manyika, 2012). The successful adoption, of innovative manufacturing practices, require players in this domain to be supportive of these practices, and to be willing to step forward, when it comes to the introduction of new approaches. This represents the basic route towards realizing what is known as the 'factory of the future' (KPMG, 2016).

\section{Industry $\mathbf{4 . 0}$}

In 2015, the International Controller Association (ICA) reported that the significance of industrial revolutions is globally acknowledged and well-understood. The initial industrial revolution began with the introduction of the steam engine, followed gradually by the fabrication of mechanical manufacturing implements. The second industrial revolution was characterized by the replacement of steam energy, by electricity. This led to the launching of the assembly line and conveyor belt. The arrival, of the third industrial revolution, was signalled by the mechanization of manufacturing processes, through the use of electronics, as well as the employment of information and communication technologies (Horváth and Michel, 2015). Following three industrial revolution phases, we are now privy to the fourth industrial revolution. This industrial revolution phase was initially cited by the federal government of Germany in 2011 (Roblek, Meško, and Krapež, 2016, Mohamad, et al, 2018, Mohamad, et al, 2019). Often used in the same vein, the expressions loT, fourth industrial revolution, industry 4.0 and cyber-physical systems, are currently in the limelight ( Mohamad, et al, 2019, Dittrich, 2016). Industry 4.0 portrays a new industrial era, founded on advancements in communication and technology, and characterized by hyper-connectivity and super intelligence. Generally, industry 4.0 involves the blending of all the real world's services and products, with new technologies, in different domains. This includes the domains of 3D printing, robotics, biotechnology, and nanotechnology (Mohamad, et al, 2019, Dittrich, 2016, Jee, 2017). Professor Klaus Schwab, the Founder and Executive Chairman of the World Economic Forum (WEF) stated that, "The fundamental and global nature of this revolution, also poses new threats related to the disruptions it may cause, affecting labour markets and the future of work, income inequality, and ethical frameworks" (Lanvin and Evans, 2016). It is probable that indifference to these issues will result in significant consequences (for businesses, societies and individuals) "not limited to growing inequality, widening skills gaps, massive dislocation of jobs and talent shortages" (Mohamad, et al, 2019, WEF, 2016)

\subsection{Systems and Technologies with Regards to Industry 4.0}

The employment, of regular internet-established procedures, can facilitate interaction, between the linked systems, for data analysis and failure prediction, as well as for the system's configuration. Industry 4.0, the fourth surge in technological progression, can be described as a conversion derived through nine advances in technology. These advances are illustrated in Figure 1. 


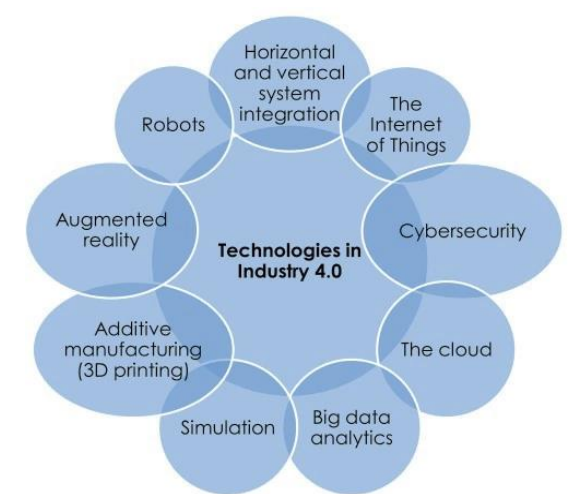

Figure 1. The nine pillars of technological advancement (Bahrin, Othman, Azli, and Talib, 2016).

The technological advancements associated to industry 4.0, are defined as the nine pillars (building blocks) that make possible, the accumulation and analysis of data through machines. This renders the manufacturing process for high-quality goods quicker, more adaptable, and cost-effective (Sirkin, Zinser, and Rose, 2015). In keeping with this hypothesis, by exploiting the exceptional connectivity and considerable quantity of accessible information, manufacturing systems will be able to independently direct and improve themselves, with minimal human involvement B(onekamp and Sure, 2015)

\subsection{Industry 4.0 and Human Capital}

Currently, the manner, in which individuals learn, live and work, is significantly determined by the technological advancements associated to industry 4.0. Dexterity, expertise and work organization are essential elements, for managing the altered economic and social conditions, which are expected to be basically different (UNSECO, 2017). Human capital management can play a crucial role in the generation of dynamic capabilities, by offering an environment conducive to innovation and effective learning (Shamim, Cang, Yu, and $\mathrm{Li}, 2016$ ). Additionally, a revamp of the education and training systems, aimed at equipping workers with the expertise required for engaging new automated processes, ought to be in the pipeline (Manyika, 2017). The structure, of a substantial number of present-day educational systems, is deemed inappropriate for existing, or impending labour markets. As such, it is essential that educational establishments stay abreast of technological advancements, so as to bridge the gap between formal education, and the labour market (Samans, Zahidi,and Leopold, 2017). While John Maynard Keynes (1930) foresaw the speedy advancement of technology, over the following nine decades, he is also known for his claim that "We are being afflicted with a new disease of which some readers may not have heard the name, but of which they will hear a great deal in the years to come-namely, technological unemployment" (Keynes, 2010). Mr Smith, Rolls-Royce's manufacturing person in charge, opined that "If manufacturing matters, then we need to make sure the necessary building blocks are there in the education system" (Markillie, 2012) An article in the MENA Report, points to the evident discrepancy, between expertise and job requirements, with regards to the Middle East and the North African localities. In these regions, the growth of $40 \%$ of businesses is hampered by the lack of required skills. Business leaders in general, regret the fact that many countries are still groping in the dark, when it comes to the recruitment of employees with the required skills (WEF, 2017)

In 2012, the African Economic Outlook (AEO) reported that Libya is currently on a rocky road, represented by youth unemployment and many other issues. These issues need to be properly managed, to enhance the country's economic and political stability, and consequently deter the occurrence of social upheavals. Over the last three decades, the Libyan leadership has struggled to come up with an appropriate and practical approach, for promoting youth employment, and improving the standard of education (AEO, 2012). While the small population of Libya is supposedly blessed with prosperity, the dearth of knowledgeable manpower (particularly in terms of its youth), remains the most prominent stumbling block to economic development and technological advancement. This can be attributed to the disagreement between the skills promoted by the education system, and the skills required by the labour market. While employment in Libya's manufacturing division took a dive from $7.3 \%$ to $5.8 \%$, eighty percent of private businessmen, consider 
the expertise and working attitude of their foreign employees, to be superior to those of their Libyan employees. In the context of human resource development, Libya will stand to gain, by tapping into the experience of developed countries (Braun and Jones, 2013).

The limited amount of information, offered by the Libyan labour market information system (LMIS), comes in the form of collective employment records posted by government ministries. The lack of reports on the elements of quantity and quality, with regards to public sector employment, renders such information inconsequential. It is undeniable, that reliable information, on the difficulties confronting the labour market of Libya, is hard to come by (Abuhadra and Ajaali, 2014). While Libya can boast of a considerably elevated school registration rate, it is ironical that in 2012, this country was burdened with a youth unemployment rate of $48 \%$, and a female unemployment rate of $25 \%$. Prior to the unrest in 2011, the 2010 Investment Climate Assessment (ICA) revealed that thirty percent of Libyan organizations, considered the recruitment of skilled Libyan nationals, a fruitless exercise. Roughly $60 \%$ of Libya's labour force is made up of Libyan nationals, while the remaining $40 \%$ is made up overseas employees (WBG, 2018).

According to information gleaned from relevant literature, the expanding skills gap is attributed to the indifference towards two issues: education, and training of the existing workforce. If Libya is to stay abreast of technological advancements, it is essential that these two issues be taken into account.

\section{Education}

In the context of education, the emphasis should be on a system that meets the immediate requirements. Decisions regarding the objectives of educational reform, are generally in the hands of the current institutional stakeholders (Tuomi and Miller, 2011). For the past fifty years, researchers have devoted much time and effort, into studying the progression mode of industries, and the effect of environmental movements, on the structure and operations of institutions. Towards the close of the twentieth century, among the main concerns, was the incapability of educational establishments, to raise their productivity levels, and fulfil manpower requirements (Murphy and Mayborn, 2013). A college degree and comprehensive knowledge, does not guarantee an individual's good performance, as a worker in the 'factory of the future' (Gehrke et al., 2015). In 2016, the human capital report, on the problem-ridden transition from education to employment, accentuated the need for upcoming generations, to be equipped with the skills and knowledge required, for employment in factories with advanced technological applications (World Economic Forum, 2016).

\section{Training of Existing Workforce}

Employers frequently target highly-skilled individuals, in order to do away with the need for training programmes. This attitude is a significant contributing factor, towards youth unemployment (Lanvin and Evans, 2016). It would be ideal, if companies could offer a variety of training programmes, aimed at equipping their workers with multitasking capabilities (BERGER, 2016)

\section{Research Methodology}

A comprehensive appraisal of relevant literature was conducted to scrutinize the aspects of industry 4.0. This included its pillars, features and potential downsides. This literature appraisal exposed the scarcity of investigations conducted in this area. The quantitative method was favoured for this study, as it is deemed most suitable for an assessment of the skills gap. The initial objective, of our survey, is to ascertain the existing skill level of the stakeholders themselves, with regards to the skills essential for their involvement in industry 4.0. An investigation carried out by Roland Berger (BERGER, 2016) revealed that the necessary skills can be separated into four categories. These categories are illustrated in Figure 2.

\subsection{Survey Approach}

The participants for this survey included policy makers, employers/employees, teachers/students and the unemployed. In keeping with the survey guidelines, other than compliance to the agreed upon conditions, other aspects including gender, age, education and region of origin were taken into account. Following the formulation of the questionnaire, randomly selected participants, were posted an email, delivering a concise explanation on the survey, as well as a link to the website 
serving as host to the questionnaire. Utilizing a web browser, participants tendered their replies to the survey monkey website (http://www.surveymonkey.com). Participants were guaranteed total confidentiality in all aspects, with regards to their involvement in this survey. The questionnaire comprised the following eight segments. Segment 1 holds questions aimed at eliciting general information on the participant. This includes gender, age, academic qualifications, employment status, sector and residential location (Table 1).

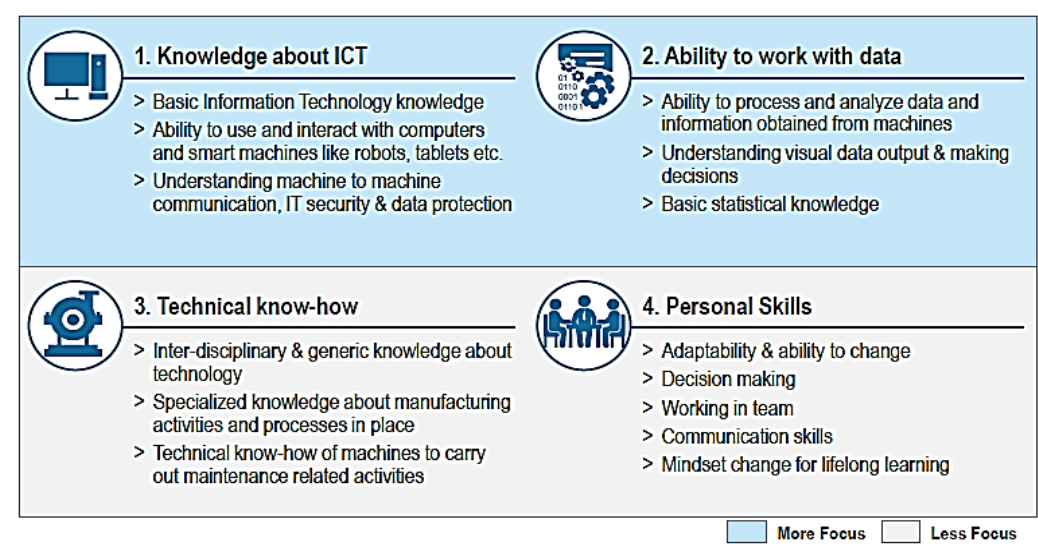

Figure 2. Important qualifications \& skills to have for industry 4.0 [33]

Segment 2 involves the gathering of information from all target groups regarding their awareness about industry 4.0. Section 3 emphasizes on the rating of existing skills with regards to the skills required for industry 4.0. The questions in Section 4 are framed to assess the educational systems in Libya. Section 5 delves into the obstacles to employment encountered by the youths in Libya. Section 6 emphasizes on questions regarding the steps taken by Libyan industry players, to tackle the skills gap issue. Section 7 is made up of questions related to the relationship between industries and the academic domain. And lastly, Section 8 focuses on the readiness of Libyan industrial divisions, to assume the practices of industry 4.0. Upon the accumulation of 326 responses, data was extracted from the survey monkey website, and delivered to the SPSS software package for analysis.

Table 1. Demogpahic characteristics of respondents

\begin{tabular}{|c|c|c|c|c|c|c|c|c|c|}
\hline \multicolumn{9}{|c|}{ Variable } & Total \\
\hline Gender & Male & Female & & & & & & & \multirow[b]{2}{*}{326} \\
\hline $\begin{array}{c}\text { Frequency } \\
\text { Percent }\end{array}$ & $\begin{array}{l}232 \\
71.2\end{array}$ & $\begin{array}{c}94 \\
28.8\end{array}$ & & & & & & & \\
\hline Age Group & $\begin{array}{l}15-18 \text { years' } \\
\text { old }\end{array}$ & $\begin{array}{c}19-24 \\
\text { years old }\end{array}$ & $\begin{array}{c}25-34 \\
\text { years old }\end{array}$ & $\begin{array}{l}35-44 \text { years } \\
\text { old }\end{array}$ & $\begin{array}{l}45-54 \text { years } \\
\text { old }\end{array}$ & $\begin{array}{l}55 \text { years } \\
\text { and over }\end{array}$ & & & \multirow[b]{2}{*}{326} \\
\hline $\begin{array}{c}\text { Frequency } \\
\text { Percent }\end{array}$ & $\begin{array}{c}4 \\
1.2\end{array}$ & $\begin{array}{c}41 \\
12.6 \\
\end{array}$ & $\begin{array}{c}143 \\
43.9 \\
\end{array}$ & $\begin{array}{c}101 \\
31.0 \\
\end{array}$ & $\begin{array}{l}31 \\
9.5\end{array}$ & $\begin{array}{c}6 \\
1.8 \\
\end{array}$ & & & \\
\hline $\begin{array}{c}\text { Academic } \\
\text { Qualification }\end{array}$ & $\begin{array}{l}\text { Less than a } \\
\text { high school } \\
\text { diploma }\end{array}$ & $\begin{array}{c}\text { High } \\
\text { school } \\
\text { degree or } \\
\text { equivalent }\end{array}$ & $\begin{array}{c}\text { Bachelor's } \\
\text { degree }\end{array}$ & $\begin{array}{c}\text { Master's } \\
\text { degree }\end{array}$ & $\begin{array}{c}\text { Professional } \\
\text { degree }\end{array}$ & Doctorate & Other & & \multirow[t]{2}{*}{326} \\
\hline $\begin{array}{c}\text { Frequency } \\
\text { Percent }\end{array}$ & $\begin{array}{c}4 \\
1.2\end{array}$ & $\begin{array}{l}28 \\
8.6\end{array}$ & $\begin{array}{l}141 \\
43.3\end{array}$ & $\begin{array}{l}110 \\
33.7\end{array}$ & $\begin{array}{c}2 \\
0.6\end{array}$ & $\begin{array}{c}36 \\
11.0\end{array}$ & $\begin{array}{c}5 \\
1.5\end{array}$ & & \\
\hline $\begin{array}{l}\text { Employment } \\
\text { status }\end{array}$ & Policymakers & Employer & Employee & $\begin{array}{c}\text { Self-employe } \\
d\end{array}$ & Unemployed & Student & Teacher & Other & \multirow[b]{2}{*}{326} \\
\hline $\begin{array}{c}\text { Frequency } \\
\text { Percent }\end{array}$ & $\begin{array}{c}9 \\
2.8 \\
\end{array}$ & $\begin{array}{c}8 \\
2.5 \\
\end{array}$ & $\begin{array}{c}76 \\
23.3 \\
\end{array}$ & $\begin{array}{c}17 \\
5.2 \\
\end{array}$ & $\begin{array}{c}57 \\
17.5 \\
\end{array}$ & $\begin{array}{c}99 \\
30.4 \\
\end{array}$ & $\begin{array}{c}39 \\
12.0\end{array}$ & $\begin{array}{l}21 \\
6.4\end{array}$ & \\
\hline Sector & Education & Oil and Gas & ICT & $\begin{array}{l}\text { Electricity } \\
\text { and Water }\end{array}$ & $\begin{array}{c}\text { Manufacturin } \\
\mathrm{g}\end{array}$ & Other & & & \multirow[b]{2}{*}{170} \\
\hline $\begin{array}{l}\text { Frequency } \\
\text { Percent }\end{array}$ & $\begin{array}{l}62 \\
36.7\end{array}$ & $\begin{array}{c}9 \\
5.0\end{array}$ & $\begin{array}{c}20 \\
11.5\end{array}$ & $\begin{array}{l}12 \\
7.2\end{array}$ & $\begin{array}{l}51 \\
11 \\
6.5\end{array}$ & $\begin{array}{c}56 \\
33.1\end{array}$ & & & \\
\hline Region & $\begin{array}{c}\text { West } \\
\text { (Tripolitania) }\end{array}$ & $\begin{array}{c}\text { East } \\
\text { (Cyrenaica } \\
\text { ) }\end{array}$ & $\begin{array}{c}\text { South } \\
\text { (Fezzan) }\end{array}$ & & & & & & \multirow{2}{*}{326} \\
\hline $\begin{array}{c}\text { Frequency } \\
\text { Percent }\end{array}$ & $\begin{array}{l}174 \\
53.4\end{array}$ & $\begin{array}{c}131 \\
40.2\end{array}$ & $\begin{array}{l}21 \\
6.4\end{array}$ & & & & & & \\
\hline
\end{tabular}

\subsection{Target group compilation}

The selection of the target group is determined by the study objectives, as illustrated in Table 2 . 
Table 2. Plan how to reach defined research objectives by target group selection

\begin{tabular}{|c|c|c|c|c|c|c|}
\hline \multirow[t]{2}{*}{ No } & \multirow[t]{2}{*}{ Objective } & \multirow[t]{2}{*}{ Section } & \multirow[t]{2}{*}{ Target Group } & \multicolumn{2}{|c|}{ Frequency } & \multirow[t]{2}{*}{ Total } \\
\hline & & & & Valid & Missing & \\
\hline 1 & Awareness & 2 & All target groups & 326 & 0 & 326 \\
\hline 2 & current skill level & 3 & All target groups & 326 & 0 & 326 \\
\hline \multirow{4}{*}{3} & \multirow{4}{*}{$\begin{array}{l}\text { The Causes of } \\
\text { Widening Skill Gap }\end{array}$} & 4 & Students & 99 & \multirow{4}{*}{0} & \multirow{4}{*}{326} \\
\hline & & 5 & Unemployed & 57 & & \\
\hline & & 6 & \multirow{2}{*}{$\begin{array}{l}>\text { Policymakers/ Employer } \\
>\text { Employee/ Self-employed } \\
>\text { Teacher } \\
>\text { Other }\end{array}$} & \multirow[t]{2}{*}{170} & & \\
\hline & & 7 & & & & \\
\hline 4 & Readiness & 8 & $\begin{array}{l}>\text { Policymakers/ Employer } \\
>\text { Employee/ Self-employed } \\
>\text { Teacher } \\
>\text { Other }\end{array}$ & 170 & 156 & 170 \\
\hline
\end{tabular}

\section{Elaboration of Data and Analysis of Accumulated Responses}

\subsection{Awareness Regarding Industry 4.0}

According to the survey results, the majority $(75.5 \%)$ of Libyan stakeholders are in the dark regarding industry 4.0 , while the rest $(24.5 \%)$ shared that their awareness and familiarity with regards to industry 4.0 was derived through the internet (Figures $3 a$ and $3 b$ ).

Awareness and Familiarity on "Industry 4.0"

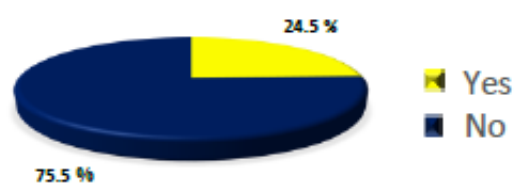

Figure 3a. Pie chart indicating the level of awareness and familiarity regarding industry $4.0^{\prime \prime}$

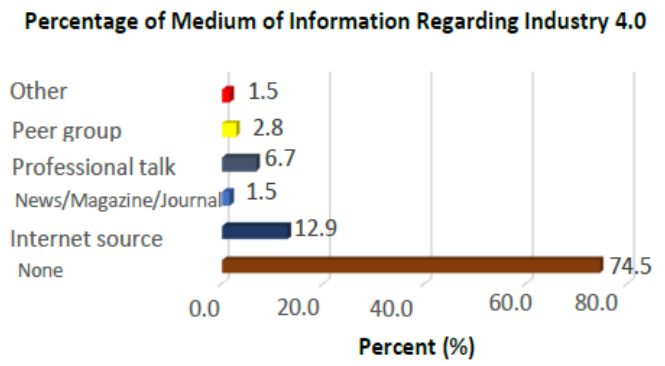

Figure 3b. Bar chart indicating the percentage of industry 4.0 information derived through various mediums

\subsection{The Skills Gap in Relation to Industry 4.0}

The survey delved into the gaps that prevail, between the required skills for industry 4.0 , and the perceived existing level of skills (Figure 4).

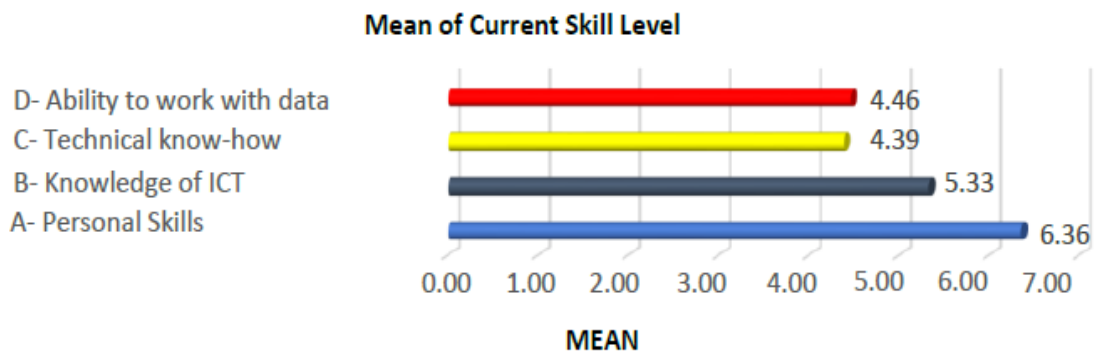

Figure 4. Bar chart portraying assessment of mean, with regards to the existing skill level (on a scale of 1 to 10$)$ 
The skills gaps were computed as the discrepancy between each required industry 4.0 skill, and the respondents' ranking of their own existing skill level. Skill gaps were graded, to identify those that respondents' needed to improve on the most. The area with the widest skill gap was identified as technical know-how (4.39). Respondents also perceived rather extensive skill gaps, when queried about their expertise for working with data (4.46). The respondents' perceived elevated skill level (mean score greater than 5.0), with regards to personal skills and ICT knowledge, is an indication that the skill gaps for these two areas are lesser. The mean rating for knowledge of ICT was recorded as 5.33 , while the mean rating for personal skills was recorded as 6.36 . These areas denote the skills with the slightest gap. Notably, the mean rating of personal skills can be considered satisfactory.

\subsection{Expanding Skills Gaps}

\section{A. Effectiveness of Education Systems}

The Libyan educational establishments' preparedness for industry 4.0 , and the upgrading of skills, was delved into. According to the survey results, Libyan educational establishments are currently wanting in preparedness for these areas. The respondents graded these establishments below average in vital areas (Figure 5)

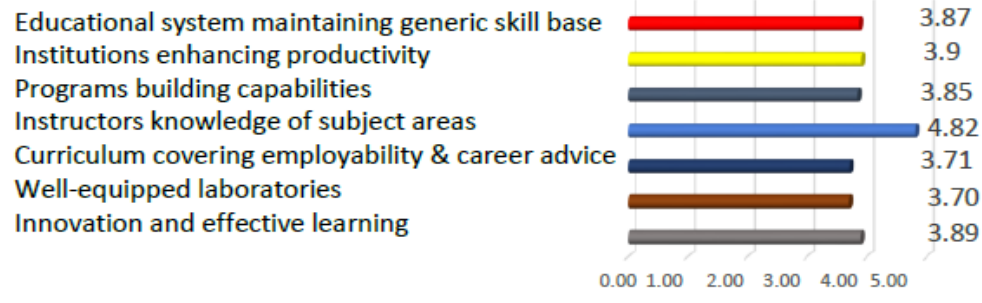

MENA

Figure 5. Bar chart for assessment of educational quality (on a scale 1 to 10 )

In the opinion of Braun and Jones [26], among the most daunting tasks of a transformation programme, is the reorganization of the whole education system. Respondents' quotations, regarding their assessment of the education system, and the know-how of graduates, are provided in Table 3.

Table 3. Assessment of the education system by quotations from respondents [26]

\begin{tabular}{|l|l|}
\hline \multicolumn{1}{|c|}{ Quotations from respondents } & \multicolumn{1}{|c|}{ Assessment of the education system } \\
\hline $\begin{array}{l}\text { (Head of Human Resource Department } \\
\text { of a foreign company - energy sector) }\end{array}$ & $\begin{array}{l}\text { The education system is corrupt. You cannot } \\
\text { trust an examination result. Teachers have no } \\
\text { status in the society. }\end{array}$ \\
\hline $\begin{array}{l}\text { (General Manager of a Libyan company } \\
\text { - Vocational Training Institute) }\end{array}$ & $\begin{array}{l}\text { Schools' skills are insufficient, especially } \\
\text { math/ humanities/reading and writing. } \\
\text { English language knowledge is non-existent. } \\
\text { Basic Computer skills do exist. }\end{array}$ \\
\hline $\begin{array}{l}\text { (Entrepreneur of a Libyan company - } \\
\text { conglomerate, import trade, service } \\
\text { sector) }\end{array}$ & $\begin{array}{l}\text { Graduates are certificate oriented, not } \\
\text { competency oriented. Memorizing is an } \\
\text { obstacle to analytical thinking and problem } \\
\text { solving. }\end{array}$ \\
\hline $\begin{array}{l}\text { (Technical Director - Libyan company - } \\
\text { construction) }\end{array}$ & $\begin{array}{l}\text { Curricula not oriented towards the needs of the } \\
\text { labor market. Graduates have no labor market } \\
\text { orientation. Vocational graduates are too } \\
\text { theoretical; they don't have any practical } \\
\text { experience. }\end{array}$ \\
\hline $\begin{array}{l}\text { (General Manager of a Libyan company } \\
\text { - manufacturing) }\end{array}$ & $\begin{array}{l}\text { In the education system there are a lot of } \\
\text { wrong people in the wrong positions, } \\
\text { concerning their abilities, competencies and } \\
\text { skills. }\end{array}$ \\
\hline $\begin{array}{l}\text { The education system is dead. } \\
\text { (Operations Manager of a foreign }\end{array}$ \\
\hline
\end{tabular}




\section{B. The Hiring Difficulties}

The sources of hiring difficulties are portrayed in Figure 6. Generally, the respondents are in agreement that the following, are the main impediments to the hiring of highly skilled employees: (a) candidates without the relevant working experience, (b) candidates with no technical or occupational expertise, and (c) candidates devoid of generic skills.

Conversely, the survey results indicate, that the respondents do not agree, to the following being the sources of hiring difficulties: (a) candidates' deficiency in educational qualifications, (b) reluctance of the candidate to accept the salary proposed, and (c) the extended travelling distance from residence to place of work. Unemployed Libyan youths were also posed the query "Do firms or private businessmen prefer recruiting non-Libyan employees over Libyan nationals?" Unexpectedly, almost all (94\%) the survey participants responded in the affirmative (Figure 7). This gives credence to the contention, that the preference for foreign workers is attributed to the skills gap, among Libyan youths.

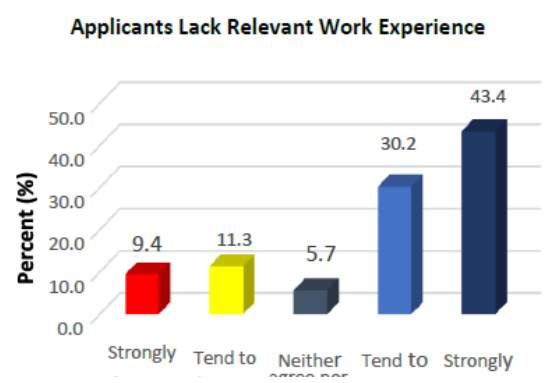

Figure 6a. The participants' attitudes and opinions, in percentages, regarding the lack of relevant work experience.

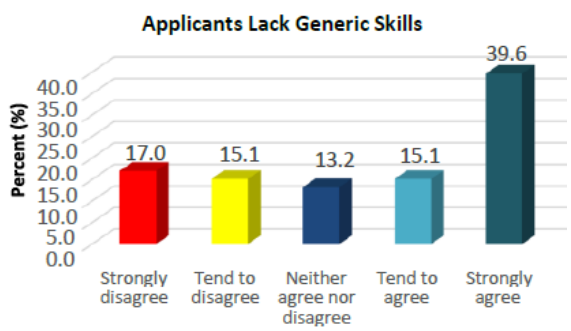

Figure 6c. The participants' attitudes and opinions, in percentages, regarding the lack of generic skills

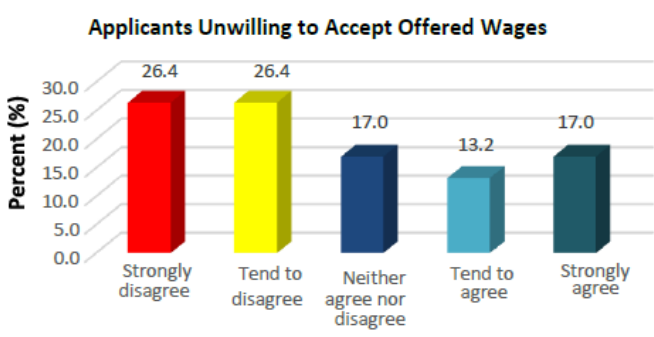

Figure 6e. The participants' attitudes and opinions, in percentages, regarding the offered wages.

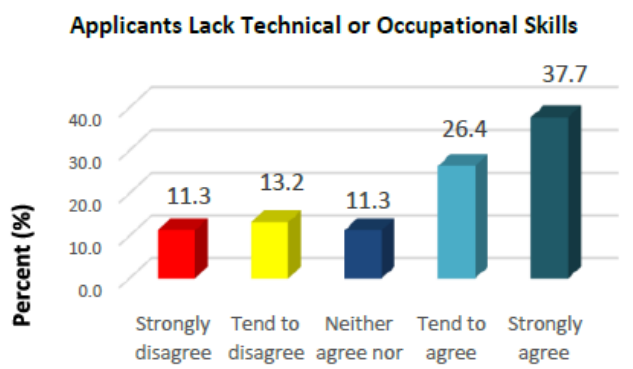

Figure 6b. The participants' attitudes and opinions, in percentages, regarding the lack of relevant work experience.

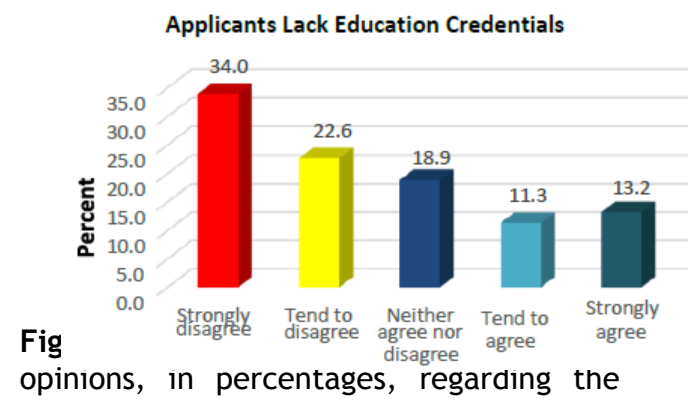

lack of educational credentials

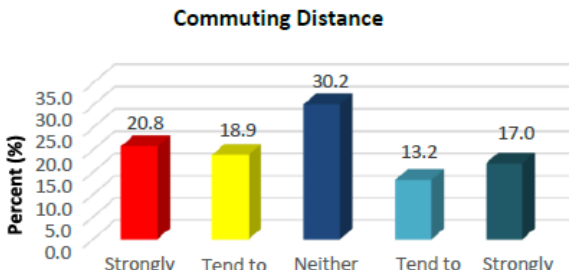

Figure 6f. The participants' attitudes and opinions, in percentages, regarding commuting distance to workplace wages. 


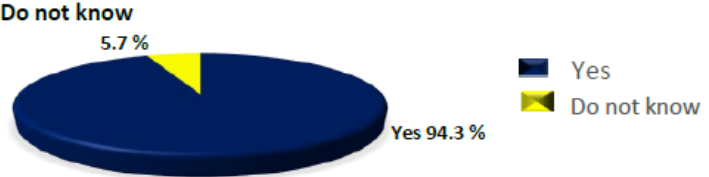

Figure 7. The participants' attitudes and opinions, in percentages, regarding preference for the recruitment of foreigners over Libyan nationals

\section{Efforts Made to Address the Skill Gaps}

Slightly more than half (59\%) the respondents in this survey, claim that their employers offer existing employees a variety of training programmes, to bridge the skill gaps (Figure 8). Organizations that opt for outsourcing to specialists and/or companies, to deal with the skill gaps, were reported by $26 \%$ of the respondents. According to $11 \%$ of the respondents, their organizations address the skill gaps, by restricting the recruitment of employees, to those already equipped with high skills.

The strategies for addressing the Skills Gap in Libya Organizations

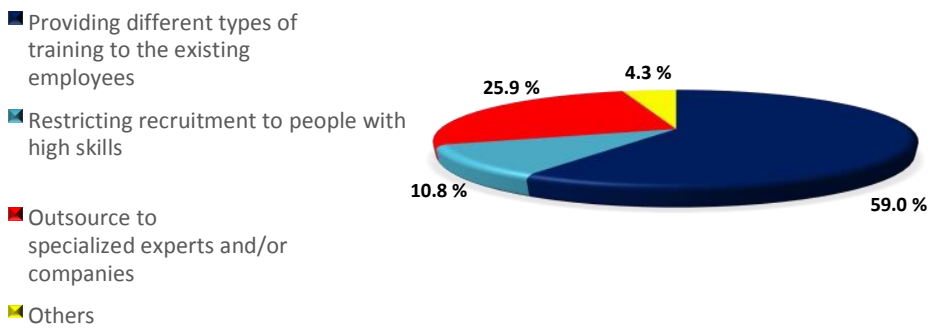

Figure 8. Pie chart portraying measures to address skill gaps in the industrial divisions of Libya

\section{Collaboration Between Industry and the Academia}

According to the survey results, a sizable portion ( $80 \%$ ) of respondents concur, that close cooperation and synergy between industries and the academia, will go a long way towards bridging the skill gap. A small portion of respondents $(1.5 \%)$ disagree with this viewpoint (Figure 9$)$. Nevertheless, $50 \%$ of the respondents graded the percentage of collaboration and synergy, between their organization and the academia, as not more than $25 \%$. This apparent lack of cooperation and synergy, between industries and the academia, could represent a significant contributing factor, towards the wide skill gap.

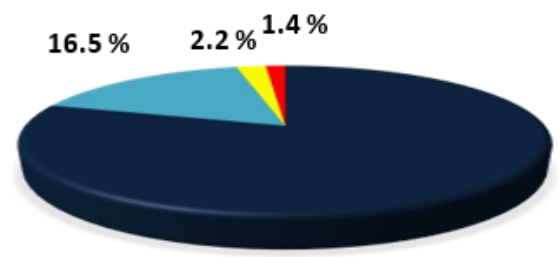

$79.9 \%$

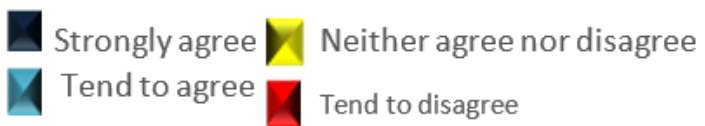

Figure 9. The participants' attitudes and opinions regarding cooperation between industry and academia 
JIE, Vol. 5, No.1, April 2020: 1-13

Cooperation between industry and academia

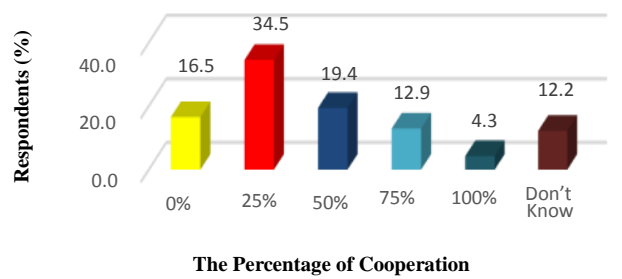

Figure 10. Bar chart for percentage of cooperation between industry and academia

\subsection{Readiness with Regards to Industry 4.0 Implementation}

In response to the query regarding the readiness of their organizations to put industry 4.0 into practice, roughly $56 \%$ of respondents were of the opinion that their organizations were rather hesitant about doing so (Figure 11). This verifies the contention that in the context of industry 4.0 implementation, Libyan organizations, production companies and institutions, have to contend with a variety of stumbling blocks.

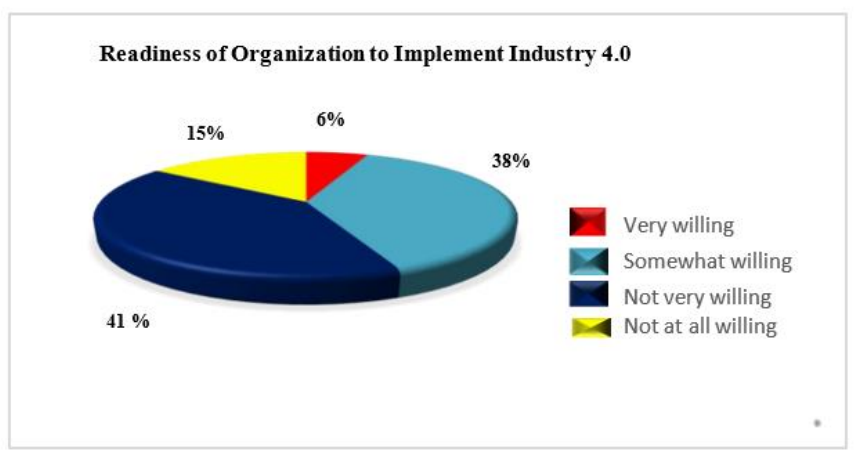

Figure 11. Pie chart portraying the degree of willingness with regards to the implementation of industry 4.0

In terms of the main impediments, to the technological changes required for industry 4.0 (Figure 12 and Table 2), the majority of respondents pointed to the following issues:

- The want of a skilled workforce (comprising technicians, specialists and engineers) seriously hampers the implementation of technical changes

- Inappropriate policies or formalities hold back technological advancements

- Lack of interest on the part of employers slows down the introduction of technological changes

- Obstacles to change in the form of financial limitations

- Inappropriate infrastructure and building

- A non-conducive investment situation

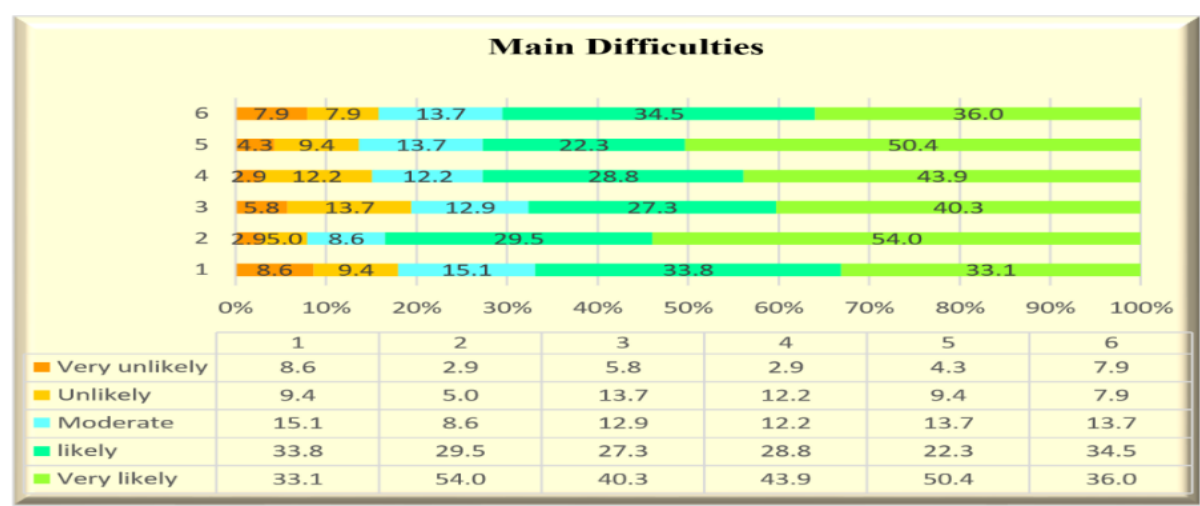

Figure 12. Bar chart portraying the main obstacles to the implementation of technological changes by organizations 
Table 4. The summary of each percentage represents the probability of having two conditions (Likely and Unlikely)

\begin{tabular}{|l|c|c|}
\hline \multicolumn{1}{|c|}{ Main Difficulties } & Likely \% & Unlikely \% \\
\hline 1. Lack of Skilled Workforce. & 67.0 & 18.5 \\
\hline 2. Policies or Red Tape. & 84.0 & 8.0 \\
\hline 3. Employers Lack of Interest. & 67.6 & 19.5 \\
\hline $\begin{array}{l}\text { 4. Budgetary or Financial } \\
\text { Constraints. }\end{array}$ & 72.7 & 15.0 \\
\hline 5. Infrastructure and Building. & 72.7 & 13.7 \\
\hline 6. Weak investment climate. & 70.5 & 16.0 \\
\hline
\end{tabular}

\subsection{Measures Proposed for A Better Comprehension of the Skills Gap, and Study Findings}

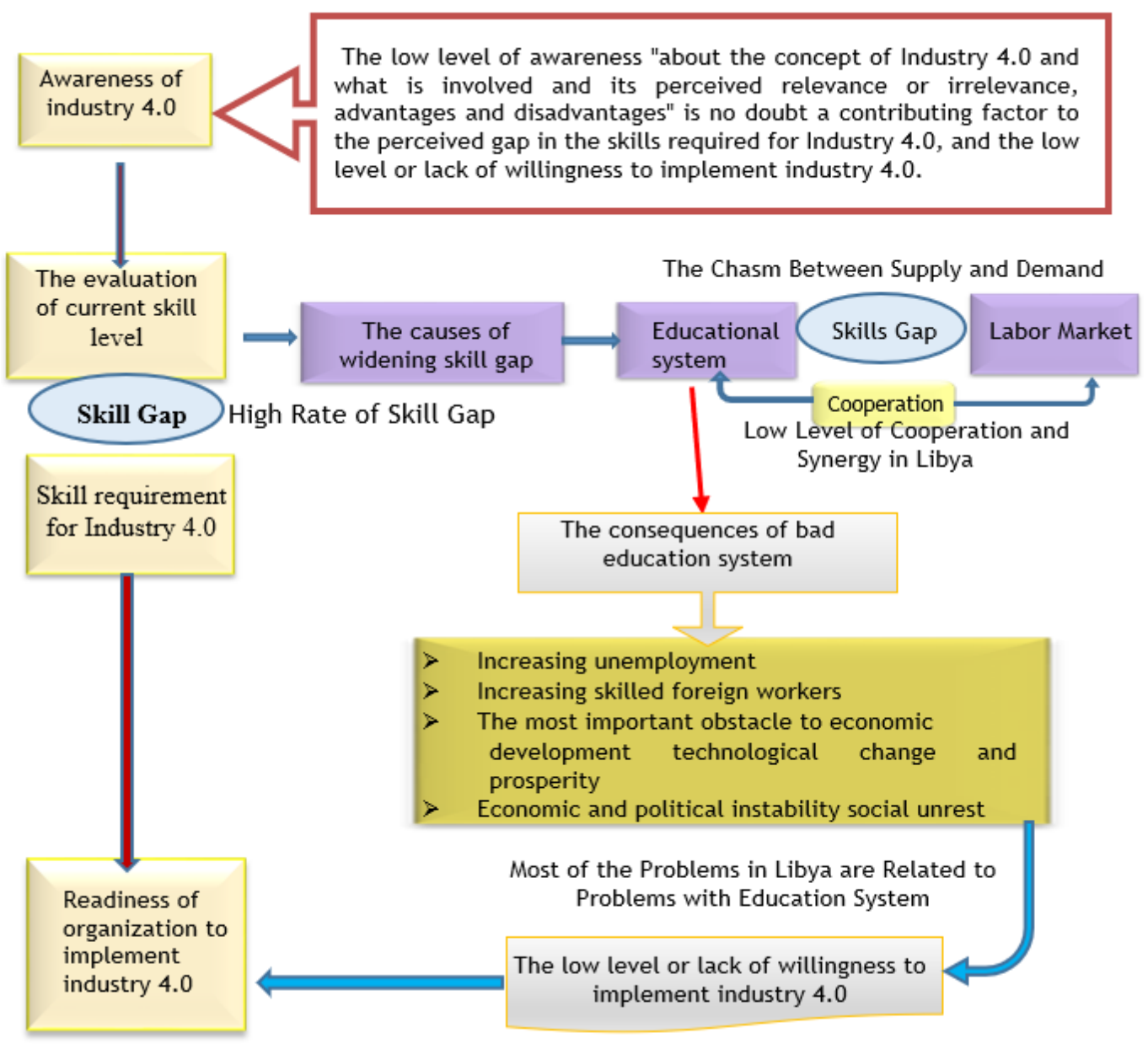

Figure 13. Proposed framework to gain a deeper understanding of the skills gap and result of the study, by author

\section{Conclusions}

The results attained through this undertaking, indicate a glaring discrepancy between the existing level of skills in Libya, and the skill sets essential for industry 4.0. The only exception, in this worrying situation, is the level of personal skills, which was rated satisfactory. Generally, this eye-opener is nothing short of disturbing. Among the illogical outcomes from this investigation, is the revelation that the number of unemployed Libyans, is rising simultaneously, with the never-ending flood of 
foreign workers into the Libyan job market. The burden of blame, for this situation, should fall squarely on the shoulders of the Libyan educational system. The emphasis on quantity, rather than on quality, in Libyan schools, has resulted in employment opportunities going the way of the more highly-skilled foreigners. In the context of job market requirements, there is no denying the fact that the Libyan education system of today, can be considered close to obsolete. While several Libyan organizations are attempting to bridge the skills gap by providing training for their current workforce, this can only be looked upon as a knee-jerk reaction. Nothing less than full cooperation, between industries and the academia, should be in the pipeline, if the skills gap in Libya is to be bridged.

This investigation also revealed the disappointing level of awareness, with regards to industry 4.0, among Libyan stakeholders. This explains the low level of preparedness portrayed by the Libyan educational system, and the unenthusiastic conduct displayed by players in the industrial domain, when it comes to the implementation of industry 4.0. The majority of the survey respondents are agree, that the implementation of technological changes by Libyan organizations, in preparation for industry 4.0, will prove to be a daunting assignment. As the fourth industrial revolution will give rise to significant technological advancements, it is imperative that the Libyan government focus on the task at hand, and avoid repeating the mistakes made, during the second and third industrial revolutions.

\section{ACKNOWLEDGEMENT}

The authors would like to thank the Fakulti Kejuruteraan Pembuatan, Universiti Teknikal Malaysia Melaka (UTeM) and Assoc. Prof. Dr. Abdulmajid Hussain Assistant Academic Attaché at Libyan Embassy, Malaysia. This research has been supported by the Libyan Ministry of higher education together with Minister of Higher Education Malaysia.

\section{References}

1. Abuhadra, D. S. and Ajaali, T. T. (2014). "Labour market and employment policy in Libya," Eur. Train. Found.

2. AEO. (2012) "Libyan Economic Outlook: Promoting Youth Employment," African Economic Outlook 2012-2013. pp. 1-13. [Online] Available at: https://www.afdb.org/fileadmin/uploads/afdb/Documents/Generic-\%0ADocuments/Libya Full PDF Country Note.pdf [Accessed 10-Jan-2018].

3. Bahrin, M. A. K. , Othman, M. F. , Azli, N. H. N. and Talib, M. F. (2016). "Industry 4.0: A review on industrial automation and robotic," J. Teknol., vol. 78, no. 6-13, pp. 137-143.

4. BERGER. (2016) "Whitepaper Summary: Skill Development for Industry 4.0," Rol. Berger GMBH. BRICS Ski. Dev. Work. Group, India Sect., pp. 1-50. [Online] Available at: http:/ / indiainbusiness.nic.in/newdesign/upload/whitepaper-summaryskill-development-for -industry-4-0.pdf [Accessed 10-Jan-2018].

5. Bonekamp, L. and Sure, M. (2015). "Consequences of Industry 4.0 on human labour and work organisation," J. Bus. Media Psychol., vol. 6, no. 1, pp. 33-40.

6. Braun, G., and Jones, A. M. E. (2013). Libya-Building the Future with Youth: Challenges for Education and Employability. Deutsche Gesellschaft für Internationale Zusammenarbeit.

7. Dittrich, P.J. (2016). "Reskilling for The Fourth Industrial Revolution . Formulating A European Strategy," Jacques Delors Institut-Berlin, Policy Pap., pp. 1-16. [Online] Available at:

https://hertieschool-f4e6.kxcdn.com/fileadmin/user_upload/DigitalSkill-JDIB-Nov2016-1.p df [Accessed 10-Jan-2018].

8. Gehrke, L. et al. (2015). "A discussion of qualifications and skills in the factory of the future: .a german and american perspective," VDI/ASME Ind., vol. 4, pp. 1-28.

9. Horváth, P. and Michel, U. (2015). "Industrie 4.0 Controlling in the Age of Intelligent Networks," Dream Car Dream Fact. ICV, pp. 1-3.

10. Jee, Y.S.. (2017). "Exercise rehabilitation in the fourth industrial revolution," J. Exerc. Rehabil., vol. 13, no. 3, p. 255.

11. Keynes, J. M. (2010). "Economic possibilities for our grandchildren," in Essays in persuasion, Springer. pp. 321-332.

12. KPMG. (2016). "The Factory of the Future: Industry 4.0 - The Challenges of Tomorrow," KPMG Web site.

13. Lanvin, B. and Evans, P. ( 2016). The Global Competitiveness Report 2016-2017. [Online] Available 
https: / www.weforum.org/reports/the-global-competitiveness-report-2016-2017-1

[Accessed 10-Jan-2018].

14. Lanvin, B. and Evans, P.. (2016). "The global talent competitiveness index," INSEAD Bus. Sch. Adecco Gr. Hum. Cap. Leadersh. Inst.

15. Markillie, P. (2012)."A third industrial revolution: Special report manufacturing and innovation," Spec. Rep. Manuf. Innov. [Online] Available at: http://www.economist.com/sites/default/files/20120421_manufacturing_and_innovation.p df [Accessed 10-Jan-2018].

16. Manyika, J. (2012). Manufacturing the future: The next era of global growth and innovation. McKinsey Global Institute.

17. Manyika, J.. (2017). "A future that works: Automation, employment and productivity," McKinsey Glob. Inst. Res. Tech. Rep., pp. 1-28.

18. Mohamad, E., Shern, T.Y. . Jamli, M.R,. Mohamad, N.A., Rahman, M. A. A, Salleh, M.R. , Oke Oktavianty and ITO, T. (2019), "Readiness of Malaysian Manufacturing Firms in Implementing Industry 4.0" ,The 29th Design Engineering System Division Lecture 2019, Tohoku University. 25-27 September 2019.

19. Mohamad,E., Sukarma,L., Mohamad, N.A, Salleh, M.R., Rahman, M.A. A, Abdul Rahman, A.A., and Sulaiman, M.A. (2018). "Review on Implementation of Industry 4.0 Globally and Preparing Malaysia for Fourth Industrial Revolution”, The Japan Society of Mechanical Engineers : The 28th Design Engineering System Division Lecture 2018, Yomitan village, Okinawa Prefecture, No.18-11 , pp. 2203_1 - 2203_10, 4-6 November 2018.

20. Murphy, J., and Mayborn, F. W.. (2013). "Schooling in the Post-Industrial World: The North Star for Leadership."

21. Naudé, W. and Szirmai, A. (2012). "The importance of manufacturing in economic development: Past, present and future perspectives,".

22. Roblek, V., Meško, M., and Krapež, A. (2016). “A complex view of industry 4.0,” Sage Open, vol. 6, no. 2, p. 2158244016653987.

23. Samans, T. A., Zahidi, R., and Leopold, S. (2017). “The Global Human Capital Report 2017," World Econ. Forum, Geneva, [Online] Available at: https://www.weforum.org/reports/the-global-human-capital-report-2017 [Accessed 10-Jan-2018].

24. Shamim, S., Cang, S., Yu, H. and Li, Y. (2016). "Management approaches for Industry 4.0: A human resource management perspective," in 2016 IEEE Congress on Evolutionary Computation (CEC). pp. 5309-5316.

25. Sirkin, H. L., Zinser, M., and Rose, J. (2015). “The robotics revolution: The next great leap in manufacturing," BCG Perspect.

26. Swezey, D. and McConaghy, R. (2011). "Manufacturing growth: Advanced manufacturing and the future of the American economy," New York Schwartz Initiat. Am. Econ. Policy.

27. Tuomi, I. and Miller, R. (2011). "Learning and education after the industrial age," Oy Mean. Process.

28. UNESCO. (2017) . “Educating for the fourth industrial revolution," UNESCO-KEDI Asia-Pacific Reg. Policy Semin., pp. 1-6.

29. WBG. (2015). Labor Market Dynamics in Libya: Reintegration for Recovery. The World Bank Group, Washington $D C$ 20433. Anailable at: https: / / doi.org/10.1596/978-1-4648-0566-0 [Accessed 10-Jan-2018].

30. WEF. (2016). "the Future of Jobs: Employment, Skills and Workforce Strategy for the Fourth Industrial Revolution," Geneva, World Econ. Forum, pp. 1-12. [Online] Available at: https://doi.org/10.1177/1946756712473437 [Accessed 10-Jan-2018].

31. WEF. (2017). "The Future of Jobs and Skills in the Middle East and North Africa: Preparing the Region for the Fourth Industrial Revolution," World Econ. Forum, Geneva, no. May, pp. 1-19. [Online] Available at: https://doi.org/10.13140/RG.2.1.3063.8241 [Accessed 10-Jan-2018].

32. Westkämper, E. (2014) "Manufacturing the backbone of the european economy," in Towards the Re-Industrialization of Europe, Springer. pp. 7-16.

33. World Economic Forum. (2016) “The Human Capital Report 2016," Geneva, World Econ. Forum, no. Geneva, pp. 1-7. [Online] Available at: http://reports.weforum.org/human-capital-report-2016/technical-notes/_ [Accessed 10-Jan-2018]. 